\title{
A ARTE DE SABER FAZER GRAFISMO NAS BONECAS KARAJÁ*
}

\author{
Manuel Ferreira Lima Filho** \\ Telma Camargo da Silva \\ Universidade Federal de Goiás - Brasil
}

Resumo: Neste artigo analisamos as representações sociais articuladas pelos grafismos aplicados nas bonecas karajá a partir do entendimento de que a cultura material está inserida em contextos sócio-ecológico-territoriais e imbricada nas dinâmicas de poder que envolvem sua produção, significação e circulação. A análise é feita a partir dos dados levantados na pesquisa coletiva que subsidiou o registro do modo de fazer e formas de expressão das Ritxoko como Patrimônio Cultural Imaterial do Brasil. A pintura dos grafismos integra o processo de fabricação das figuras em cerâmica pelas mulheres, articula o mundo simbólico karajá e revela igualmente um processo criativo próprio, decorrente de fatores exógenos como aqueles imputados pelo contato interétnico. Nesse sentido, as ceramistas são classificadas internamente como "boas ceramistas" a partir de categorias que interligam arte, relações de gênero, saber tradicional, inovação e prestígio.

Palavras-chave: arte, bonecas karajá, cultura material, grafismo.

Abstract: This article analyses the social representations of graphisms on Karajá dolls based on the idea that material culture is embedded in socio-ecological-territories contexts and interconnected to the dynamics of power involved within its production, meaning and circulation. The study is based on the data collected by a research group which informed the registry of "how to do" and "the expression forms" of

* Este artigo retoma reflexões e dados contidos nos relatórios técnicos elaborados por Telma Camargo da Silva (2010), intitulado Primeiras aproximações ao grafismo aplicado às Ritxoko - Aldeia Santa Isabel do Morro (Hawaló) - Ilha do Bananal (TO); e por Manuel Ferreira Lima Filho (2010), intitulado Considerações sobre o grafismo karajá na perspectiva dos Karajá de Aruanã (GO). Os relatórios integram o projeto "Bonecas karajá: arte, memória e identidade indígena no Araguaia", desenvolvido por equipe do Museu Antropológico e Faculdade de Ciências Sociais (PPGAS), da Universidade Federal de Goiás.

**Pesquisador do Conselho Nacional de Desenvolvimento Científico e Tecnológico (CNPq).

Horizontes Antropológicos, Porto Alegre, ano 18, n. 38, p. 45-74, jul./dez. 2012 
the Ritxoko as Patrimônio Cultural Imaterial do Brasil. The graphisms drawing is a phase of the fabrication of ceramic dolls by women which articulates Karajá symbolic world as well as unveils a singular creative process coming up from external factors as the inter-ethnical contact. From this standpoint, the ceramists are classified by the members of their group as "good ceramists" based on categories that merge art, gender relationships, traditional knowledge, creativity and prestige.

Keywords: art, graphism, material culture, Karajá's dolls.

A cultura material, em suas manifestações simbólicas, ajuda a discernir as "representações coletivas"; e que elas apontam para a reprodução social. Por isto são símbolos visiveis de identidade étnica, entendida esta em definição mais simples: os fatores raciais, culturais, etc.) que unem uma comunidade para contrastá-la de outra.

Berta Ribeiro

\section{Os Karajá, os objetos e a antropologia}

O registro das bonecas karajá como Patrimônio Cultural Imaterial do Brasil, nas categorias ofício e modos de fazer e formas de expressão, ${ }^{1}$ sugere uma reflexão que articule essas duas dimensões do artefato na vida social do povo Iny. ${ }^{2}$ Nesse texto propomos analisar as representações sociais articuladas pelos grafismos ${ }^{3}$ aplicados a esse artefato cerâmico evidenciando os aspectos que o caracterizam também como expressão de arte na vida social de seus produtores. Se o grafismo e a forma das figuras modeladas remetem ao universo social e cosmológico karajá, a maneira como os desenhos são feitos nas

\footnotetext{
1 A pesquisa que subsidiou o registro, aprovado em 25 de janeiro de 2012, foi financiada no ano de 2008, pela Fundação de Apoio à Pesquisa do Estado de Goiás (Fapeg), e recebeu apoio da Secretaria de Estado de Políticas Públicas para Mulheres e Promoção da Igualdade Racial (Semira). Em 2010, o projeto contou com a parceria e financiamento do Instituto do Patrimônio Histórico e Artístico Nacional (Iphan), Superintendência de Goiás. A equipe em campo foi composta pelos antropólogos Manuel Ferreira Lima Filho, Nei Clara de Lima, Rosani Moreira Leitão e Telma Camargo da Silva.

2 Autodenominação.

3 O modo de fazer a Ritxoko - boneca de cerâmica na fala feminina - foi objeto da etnografia (Lima et al., 2011) que compôs o dossiê que subsidiou o registro.
} 
bonecas singulariza algumas ceramistas no contexto em que esse ofício é parte do processo de socialização feminina. Logo, as bonecas expressam através do grafismo as representações Iny ao mesmo tempo em que "saber fazer" o desenho insere algumas mulheres em uma rede social de prestígio. Essa perspectiva de análise coloca este estudo em diálogo com as recentes reflexões a respeito da cultura material no contexto teórico da antropologia.

$\mathrm{Na}$ trajetória da produção do conhecimento antropológico, a cultura material sempre suscitou reflexões. Malinowski (1978), com a descrição da canoa trobriandesa e os colares do kula, assim como o estudo de Mauss (2003) e o sistema de trocas do potlach, são exemplos clássicos. Em tempos atuais, ressaltamos as reflexões de Appadurai (2006) e Kopytoff (2006), inspirados numa "antropologia das coisas": as circulações dos objetos, os valores atribuídos a eles e suas trajetórias equivalem ao status de uma biografia da vida social, e Johannes Fabian (2010), que enfatiza o papel da cultura material no processo de reorientações epistêmicas da antropologia tal como a questão literária na discussão da cultura como texto.

Nesse sentido, os objetos, enquanto testemunhas de uma paisagem da memória coletiva (Silveira; Lima Filho, 2005), igualam-se a textos etnográficos produzidos a partir de trocas comunicativas e performances nas quais o etnógrafo é um participante ativo (Fabian, 2010). A cadeia operatória da fabricação dos objetos é pensada nas dimensões polifônicas e hermenêuticas, ou seja, uma "antropologia dos sentidos". ${ }^{4}$

Por sua vez, Fabio Mura (2011) desenvolve a ideia de que o objeto pode igualmente ocupar o lugar de sujeito social, alinhando-se dessa forma à declaração de Henry Jeudy de que o objeto teria um caráter antropomórfico "pensando sobre nós" (Jeudy, 2005; Lima Filho, 2006).

No Brasil, nos últimos anos, o tema da cultura material ganhou novo interesse acadêmico relacionando-se aos estudos dos patrimônios. Destacamos as reflexões pioneiras de José Reginaldo dos Santos Gonçalves (2007) sobre as noções de cultura e de ressonâncias relacionadas aos estudos de objetos, das coleções e dos museus; os de Silveira e Lima Filho (2005) sobre objetos, documentos e paisagem cultural; e ainda uma refinada análise etnográfica de Fábio Mura (2010) sobre os Kaiowa e os chiru. Este autor também se

4 Ver as considerações de Lima Filho (2012).

Horizontes Antropológicos, Porto Alegre, ano 18, n. 38, p. 45-74, jul./dez. 2012 
posiciona no debate em torno do perpectivismo. Para ele, as análises do tema da cultura material relacionadas aos grupos ameríndios tendem ou para um determinismo técnico ou para um determinismo simbólico e social, que reforçam a dicotomia natureza/cultura inicialmente criticada. Em contraposição a essas perspectivas teóricas, Mura (2011, p. 120) propõe:

Em alternativa a esse proceder, proponho um enfoque processual, que busca o sentido das concatenações técnicas a partir de contextos sócio-ecológico-territoriais específicos, não transcendendo a prática efetiva dos sujeitos - sejam eles humanos ou não humanos -, dando ênfase às intencionalidades políticas, às relações de poder e às necessidades de uso, bem como à confrontação de diferentes designs.

É pois nesse contexto conceitual que nos propomos a dialogar com o saber fazer o grafismo, arte das mulheres karajá do Brasil Central.

Situados no vale do rio Araguaia, os Karajá são classificados na perspectiva linguística como Jê do Brasil Central e apresentam modos de falar específicos em cada um dos três subgrupos karajá (karajá, javaé e xambioá). Por sua vez, em cada um dos subgrupos há uma maneira específica de fala marcada pelos gêneros feminino e masculino (Rodrigues, A., 1986).

Inserido na bacia do rio Araguaia e sua diversificada rede de tributários e lagos, o território karajá compreende desde as aldeias da cidade de Aruanã, em Goiás, até aquelas mais ao norte, no estado do Pará e Mato Grosso, passando pelas grandes aldeias na ilha do Bananal, situada no estado do Tocantins.

Na perspectiva etnológica, os Karajá apresentam alguns costumes em comum com os demais Jê, como a uxorilocalidade e o espaço ritual masculino. Contudo, se distanciam deles ao construírem suas casas em linhas retas e não de forma circular e, de modo especial, por habitarem as margens do rio Araguaia, possuírem uma mitologia e rituais de forte inspiração no mundo das águas. Nesse caso, eles se aproximam dos grupos amazônicos (Lima Filho, 1994). Dessa maneira, é uma sociedade indígena portadora de formas de organização social e cultural com alta capacidade de manejar recursos tanto do cerrado - e suas variações - quanto do grande ecossistema da floresta amazônica. A ilha do Bananal reflete tal ambiente de transição ecológica.

Horizontes Antropológicos, Porto Alegre, ano 18, n. 38, p. 45-74, jul./dez. 2012 
A produção de cultura material karajá envolve técnicas de construção de casas, a tecelagem de algodão, a fabricação de artefatos de palha, madeira, minerais, concha, cabaça, córtex de árvores, miçangas, cestaria, plumária e cerâmica $^{5}$ (Lima Filho, 1999). O fato chamou a atenção de Paul Ehrenreich (1948), que pesquisou entre o grupo em 1888 e, depois, por Fritz Krause (1940-1943), no ano de 1908. Nos anos de 1938-1939 William Lipkind (1948) igualmente destacou a produção de objetos do grupo, retomada décadas depois pela descrição mais genérica de George Donahue Jr. (1982).

No ano de 2011, o modo de fazer as bonecas - Ritxoko/Ritxoo - karajá foi registrado num dossiê textual e imagético (Lima et al., 2011), e a produção cultural material ${ }^{6}$ do grupo ganha repercussão nacional.

Atividade única das mulheres, as figuras de cerâmica tiveram no passado e ainda têm uma função lúdica para as crianças, mas são também instrumento de socialização da menina, conforme estudou de modo pioneiro Maria Heloísa Fénelon Costa (1978). Nelas são modeladas dramatizações de acontecimentos da vida cotidiana e ritual, assim como personagens mitológicos. O contato imprimiu modificações quanto ao tamanho (se tornaram maiores) e ao material utilizado, como tinturas químicas. Entretanto, os motivos figurativos e padrões decorativos são mantidos pelas ceramistas mais novas, que inclusive ressaltam figuras dos mitos e dos ritos (Lima Filho, 1999, Lima et al., 2011) apesar dos padrões inovadores criados, ou seja, são produções artísticas que não são excludentes. Nesse processo de criação é que recortamos uma análise do grafismo.

Nosso estudo tem com referências as ceramistas das aldeias karajá de Santa Isabel do Morro, na ilha do Bananal (TO), com uma população de 647, e Buridina, em Aruanã, com 106 pessoas (Fundação Nacional de Saúde, 2011). ${ }^{7}$

5 O saber lidar com a cerâmica identifica os Karajá como um povo filiado a uma tradição oleira que pode indicar conexões mais remotas quando comparados aos registros etnoarqueológicos (Lima Filho, 1994, 2005, 2012; Wust, 1975).

6 Entre os trabalhos acadêmicos que escolheram o tema da cultura material karajá destacam-se: Mário Ferreira Simões (1992), Castro Faria (1959), Maria Heloísa Fénelon Costa (1978); Maria Heloísa Fénelon Costa e Hamilton Botelho Malhano (1986); Irmhild Wust (1975); Edna Taveira (1982); Sandra Lacerda Campos (2002); Chang Whan (2010) e Ana Rondon (2011).

7 Os dados demográficos atuais registram 21 aldeias karajá, com uma população de 2927 pessoas (Rodrigues, P., 2008; Fundação Nacional de Saúde, 2011). Ver ainda Lima et al. (2011).

Horizontes Antropológicos, Porto Alegre, ano 18, n. 38, p. 45-74, jul./dez. 2012 


\section{Estratégias em campo}

Para a constituição de um inventário dos grafismos e a análise de seus significados, os pesquisadores elaboraram um catálogo fotográfico com imagens de desenhos feitos nas bonecas da coleção ${ }^{8}$ constituída pela equipe do projeto "Bonecas karajá: arte, memória e identidade indígena no Araguaia" (Silva, 2010), e ainda pela identificação dos padrões de grafismo na coleção de Mário Ferreira Simões, constituída entre os anos de 1954 e $1956 .{ }^{9}$

Essa estratégia metodológica possibilitou, em campo, a identificação do mesmo desenho por diferentes ceramistas, o que revelou aspectos significantes do processo de nomeação, alguns já apontados por outros estudiosos, como veremos mais à frente. $\mathrm{O}$ uso do catálogo de imagens facilitou a interlocução entre falantes de línguas diferentes ${ }^{10}$ e permitiu evidenciar o uso de diferentes grafias ${ }^{11}$ usadas para a mesma palavra em língua karajá.

A comparação entre evidências apontadas pelo inventário de desenhos construído por nós e aqueles constituídos por outros estudiosos foi feita dentro de alguns limites. Por um lado, em alguns estudos já realizados, o foco da análise não era a pintura na boneca, mas a cestaria (Taveira, 1982), ou a pintura corporal (Ministério da Educação, 1995; Toral, 1992). Por outro lado, os estudos referentes aos grafismos aplicados à boneca cerâmica não trazem ilustração do grafismo descrito (Costa, 1978, p. 116-120) e, quando há ilustração, esta não é acompanha pela identificação do desenho (Saviola, 1995). O uso da imagem fotográfica das bonecas com foco nos grafismos foi um recurso que permitiu viabilizar o registro de aspectos formais e sua identificação pelas ceramistas, além de possibilitar uma interação maior com as mulheres, tendo como eixo articulador o oficio de "pintar" as Ritxoko.

8 Vinte e sete bonecas confeccionadas por ceramistas de Santa Isabel do Morro, acervo do Museu Antropológico da UFG.

9 As coleções de Mário Ferreira Simões pertencem ao acervo do Centro Cultural Jesco von Puttkamer da PUC-Goiás. As peças dessas coleções foram feitas por duas ceramistas consideradas mestras, a saber: Kuanijiki e Berixá, da aldeia de Santa Isabel do Morro.

${ }^{10}$ Nas situações em que as ceramistas não eram falantes da língua portuguesa, intérpretes nativos traduziram as conversas e as nominações dos desenhos como indicado nas tabelas.

${ }^{11}$ De acordo com o tradutor, a grafia de um mesmo nome encontra variações, como em relação às palavras Tyrehé-hokó (também escrita como Tyreherêko) e Itxalabu (também escrita como Isalybá, Ixalabu. Existe um processo em andamento de normatização da grafia karajá por estudantes do Curso de Licenciatura Intercultural Indígena da UFG.

Horizontes Antropológicos, Porto Alegre, ano 18, n. 38, p. 45-74, jul./dez. 2012 
Com o objetivo de construir um inventário que articulasse os grafismos inseridos nas bonecas como expressão do universo cosmológico Karajá, outras estratégias metodológicas foram usadas. Assim, construção do inventário que subsidia as reflexões aqui apresentadas contou, além do catálogo de imagens, com a realização em papel dos desenhos usados pela ceramista Mahiru, de Santa Isabel do Morro, e sua identificação. Mahiru também nomeou os grafismos ${ }^{12}$ usados como decoração de uma pousada em São Felix do Araguaia (MT), indicando os desenhos usados na decoração das bonecas.
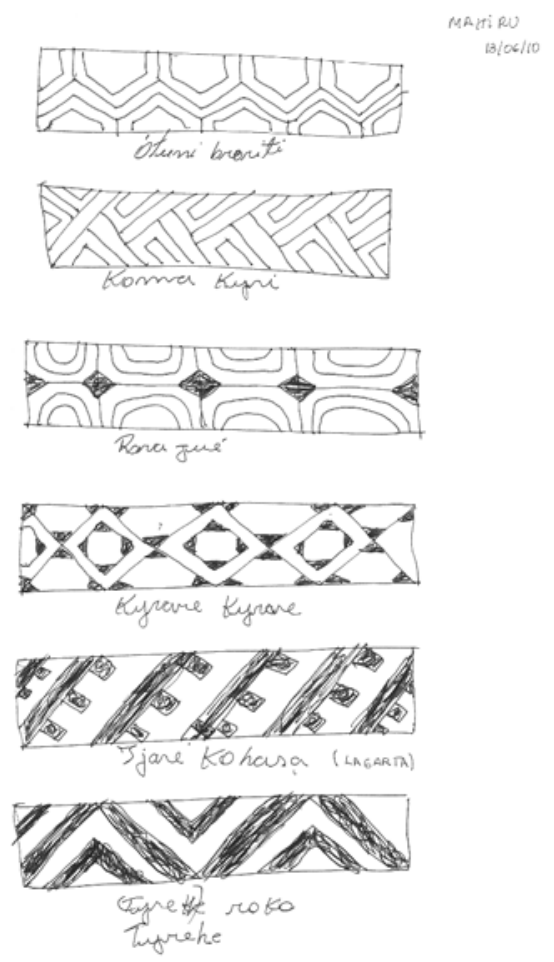

Figura 1. Grafismos desenhados em papel pela ceramista Mahiru. Dados coletados por Telma Camargo da Silva na aldeia de Santa lsabel do Morro, junho de 2010.

12 Estes desenhos foram fotografados por Telma Camargo da Silva, impressos e posteriormente apresentados por ela a Mahiru.

Horizontes Antropológicos, Porto Alegre, ano 18, n. 38, p. 45-74, jul./dez. 2012 

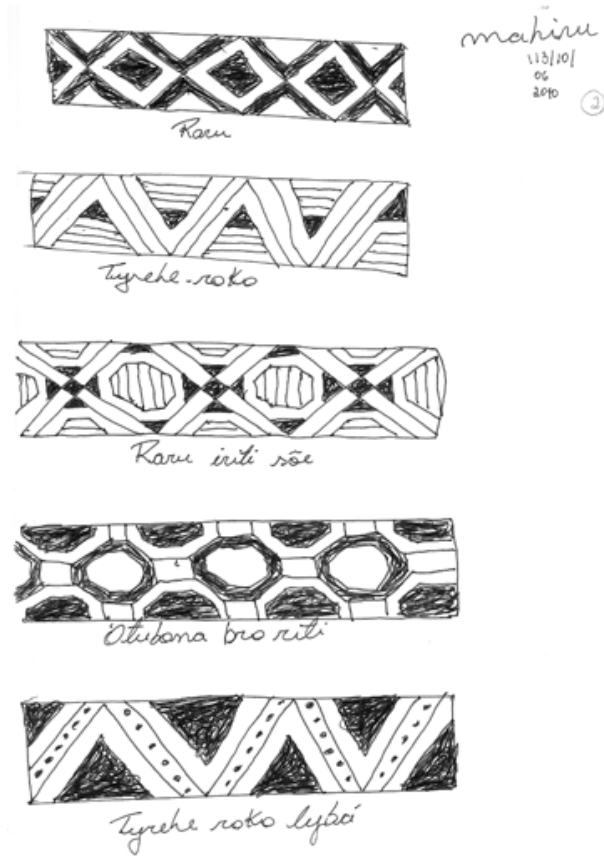

Figura 2. Grafismos desenhados em papel pela ceramista Mahiru. Dados coletados por Telma Camargo da Silva na aldeia de Santa lsabel do Morro, junho de 2010.

Enquanto o inventário possibilita a reflexão entre a elaboração da forma gráfica e sua significação no seu contexto sociocultural de produção, o falar sobre a arte do desenho e a observação da circulação dos artefatos classificados como feitos por uma "boa ceramista" permitem pensar sobre o lugar social ocupado por estas mulheres.

\section{Consideracõoes sobre aspectos formais dos grafismos $e$ as associacōoes nativas}

As Ritxoko constituem um dos vários suportes usados pelos Karajá para aplicação do grafismo.

No que se refere aos grafismos aplicados nas bonecas de cerâmica, as oleiras utilizam um pincel constituído de fina haste de palha de buriti com a ponta 
envolvida em algodão ${ }^{13}$ nativo (Costa, 1978, p. 113; Whan, 2010, p. 169). As tintas $^{14}$ mais usadas são extraídas de vegetais como o jenipapo que, misturado ao carvão, fornece a cor preta; o urucum, obtido da semente da planta do mesmo nome, fornece a cor vermelha, que também pode ser obtida do barro vermelho retirado das margens do rio Araguaia; o amarelo é obtido do tubérculo do açafrão.

Os motivos usados nas bonecas são elaborados primeiramente com a cor preta e, em seguida, complementados com a cor vermelha. Os Karajá usam padrões geométricos e associam esses motivos e suas combinações - linhas, gregas, faixas, listras - a partes do corpo, à fauna terrestre e aquática.

Embora concorde que as interpretações nativas relacionam essas formas geométricas à fauna, Maria Heloisa Fénelon Costa (1978, p. 114) chamou a atenção para a ausência de interpretações referentes a acidentes geográficos e outros objetos da natureza como rios, chuva, relâmpago e montanhas, por exemplo. Segundo ela, não existe, da mesma forma, preocupação com a flora, constituindo exceção o padrão denominado Makitíretí - desenho da cana. Ela remete a observações feitas por Ehrenreich (1948, p. 55-57) e Krause (1940-1943) para afirmar que existe uma recorrência a traços que reportam ao morcego e à cobra e que alguns traços geométricos foram tomados à técnica do trançado.

A esta observação de que os nomes dados aos motivos podem ser alusivos a epônimos animais ou vegetais, Toral (1992) problematiza os processos classificatórios acima apresentados. Primeiro, porque os sistemas nativos poderiam ser muito mais complexos do que aquele do observador em campo. Segundo, porque esse mesmo sistema classificatório, através do qual existe o esforço de apreensão de similitudes entre forma visual e natureza, não daria conta do processo criativo, gerador dos motivos. Assim, ele sugere que o desenho pode possuir nome próprio, e ele continua:

[...] originário de uma classificação que pode ser muito mais detalhada que a nossa própria quando utilizamos termos como "gregas", "desenhos geométricos" etc. Com um acervo variado de desenhos, terminaram por criar uma série de nomes cujo único fim é diferenciar conjuntos de padrões, às vezes com escassa ligação com seu epônimo vegetal ou animal. Muitas vezes, a classificação dos desenhos é feita mais por seu resultado final que pelos motivos por intermédio dos quais é feito. (Toral, 1992, p. 194).

\footnotetext{
13 Foi observado em campo que as ceramistas mais habilidosas, com a elaboração de traços mais finos, dispensam o uso do algodão.

${ }^{14} \mathrm{O}$ uso de tintas industriais também é comum entre as ceramistas.
} 
Essas considerações indicam que a construção de um inventário de padrões dos grafismos aplicados às Ritxoko como suporte material das representações do universo karajá não é tarefa fácil. Apesar da complexidade do estabelecimento dessa classificação e da identificação e denominação de padrões gráficos aplicados na decoração das figuras cerâmicas, nossas observações em campo e os dados etnográficos apontados por outros estudiosos permitem algumas considerações:

\section{As associações variáveis}

Um mesmo padrão recebe um nome distinto de acordo com diferentes informantes. Isso pode ser visto na maioria dos grafismos que foram mostrados para serem identificados pelas ceramistas. Por exemplo, como indicado abaixo, o mesmo padrão é identificado como Tyrehé-hokó (pintura de morcego), Haru e Koé-Koé.
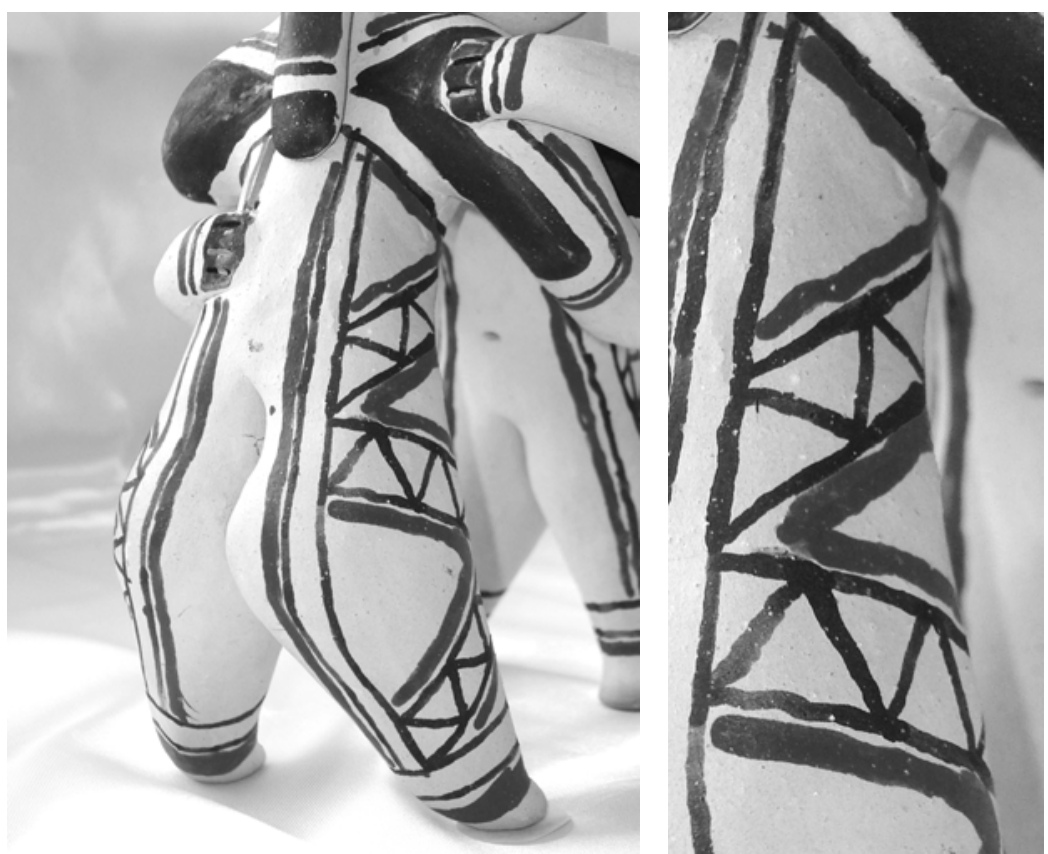

Figura 3. Conjunto de grafismos (Silva, 2010, p. 99-101). 


\begin{tabular}{|c|c|c|c|}
\hline $\begin{array}{l}\text { LOCALIZAÇÃO } \\
\text { DO GRAFISMO }\end{array}$ & NOME DO PADRÃO & SIGNIFICADO & NOME DA/DO INFORMANTE \\
\hline \multirow[t]{5}{*}{$\begin{array}{l}\text { PERNA } \\
\text { LATERAL }\end{array}$} & $\begin{array}{l}\text { Tyrehé-hóo (fala } \\
\text { masculina) } \\
\text { Tyrehé-hokó (fala } \\
\text { feminina) }\end{array}$ & $\begin{array}{l}\text { Pintura do } \\
\text { morcego }\end{array}$ & $\begin{array}{l}\text { Iracema Hakótí Karajá } \\
\text { Hamunjaka } \\
\text { (filho de Iracema) }\end{array}$ \\
\hline & Haru & & $\begin{array}{l}\text { Mahuederu } \\
\text { Mawisi (filho de Mahuederu, } \\
\text { auxiliou na tradução e na grafia) }\end{array}$ \\
\hline & Koé-Koé & Zigue-zague & $\begin{array}{l}\text { Lawarideru } \\
\text { Korihele (auxiliou na tradução e } \\
\text { na grafia) }\end{array}$ \\
\hline & Tyrehé-ròkò & $\begin{array}{l}\text { Morcego Irokò } \\
\text { (caçula) }\end{array}$ & $\begin{array}{l}\text { Kaimotí } \\
\text { Sokrowé }\end{array}$ \\
\hline & $\begin{array}{l}\text { Tyreherêko } \\
\text { Obs: A pintura é } \\
\text { feminina quando é } \\
\text { pintura corporal }\end{array}$ & Morcego & $\begin{array}{l}\text { Coaxiro } \\
\text { Txarawa (auxiliou na tradução e } \\
\text { na grafia) }\end{array}$ \\
\hline
\end{tabular}

Quadro 1. Variação na identificação de um mesmo padrão gráfico.

Essa constatação sugere que a denominação acompanha a perspectiva do olhar e da percepção da/do informante, ocorrendo as "associações variáveis" (Boas, 1947 apud Costa 1978, p. 114). Pode ser, no caso do exemplo acima:

1) a percepção de uma forma, Haru, que me sugere o triângulo;

2) a repetição da forma, formando um zigue-zague (Koé-Koé);

3) a associação feita com um elemento da natureza, no caso exemplificado um animal, o morcego (Tyrehé-ròkò);

4) pode ser, em outro exemplo, a indicação de contato interétnico ${ }^{15}$ como se depreende da afirmação de Iracema Hakóti Karajá que ao nomear um grafismo afirma que o mesmo é uma pintura kamayurá (Xingu), como na imagem a seguir:

15 Ela explicitamente diz que é em decorrência da presença de mulheres kamayurá na aldeia de Santa Isabel do Morro, referindo-se a Mavirá e sua filha Kaimotí. 

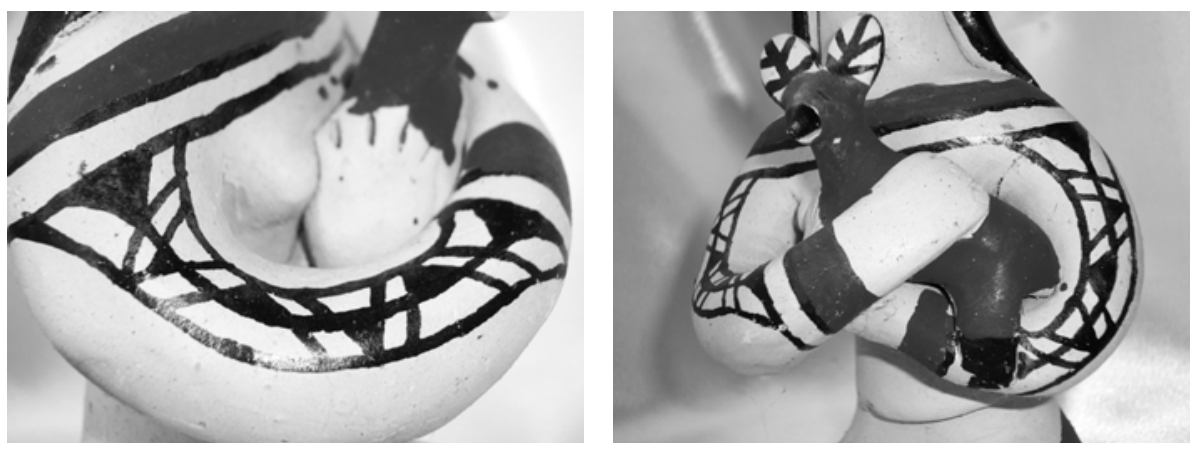

Figura 4. Conjunto de grafismos (Silva, 2010, p. 101).

A evidência empírica de que existe uma variação na denominação de um mesmo grafismo segundo a perspectiva do informante foi anteriormente observada por Costa (1978, p. 114), que afirma:

[...] outros (padrões), entretanto, são denominados de modo diferente pelos diversos informantes, e isto na mesma aldeia, o que Boas explica como se tratando de "associações variáveis" estabelecidas em relação à forma, fato de que há ocorrências em grupos da América do Norte: "Por exemplo, entre os índios da Califórnia, a mesma forma é designada por diferentes pessoas, ou às vezes pela mesma pessoa em ocasiões diversas, ora como uma pata de lagartixa, ora como uma montanha coberta de árvores $[\ldots] "$.

Essa constatação sobre as associações variáveis problematiza a análise e interpretação da relação entre a cosmologia karajá e os padrões gráficos, como afirmado acima.

\section{A relação entre os nomes dos grafismos e a natureza}

A coleção de nomes levantados que indica relações com a flora e a fauna assinala a predominância dos animais. Embora formado por um conjunto relativamente pequeno, pode-se observar que existe uma tendência maior de relacionar os nomes dos grafismos a animais que vivem na água, como indica o quadro a seguir: 


\begin{tabular}{|c|c|c|}
\hline CATEGORIA & TRADUÇÃO / LUGAR MÍTICO / COSMOLOGIA & NOME EM KARAJÁ \\
\hline $\begin{array}{l}\text { Referência } \\
\text { a animais }\end{array}$ & $\begin{array}{l}\text { CÉU } \\
\text { Flamingo (seria colhereiro?) } \\
\text { Morcego } \\
\text { Urubu } \\
\text { Urubu } \\
\text { Asa do urubu } \\
\text { Passáro (não sabe qual) } \\
\text { Pássaro (não sabe qual) } \\
\text { Gavião } \\
\text { TERRA } \\
\text { Metade da pintura do casco do jabuti } \\
\text { Pintura de tatu } \\
\text { Tamanduá } \\
\text { Lagarta } \\
\text { Jabuti } \\
\text { ÁGUA } \\
\text { Tipo de peixe (para uns) e tipo de formiga (para } \\
\text { outros) } \\
\text { Pirarucu (desenho do pirarucu) } \\
\text { Piau (desenho) } \\
\text { Pirarucu (desenho do pirarucu) } \\
\text { Pacu (desenho) } \\
\text { Jiboia } \\
\text { Jiboia } \\
\text { Tucunaré } \\
\text { Tara }\end{array}$ & $\begin{array}{l}\text { CÉU } \\
\text { Wekró-wekró } \\
\text { Tyrehé-hóo / } \\
\text { Tyrehé-hokó } \\
\text { Rará } \\
\text { Rarajie } \\
\text { Raratiederatyty } \\
\text { Haradie } \\
\text { Kuká } \\
\text { Hiré } \\
\text { TERRA } \\
\text { Otubãna bro riti ure } \\
\text { Ohã } \\
\text { Wariri } \\
\text { ljaré Kohasa } \\
\text { Kotubuma Brorite } \\
\text { ÁGuA } \\
\text { Walarodidi ou } \\
\text { Wylyhajiji } \\
\text { Hatykysi } \\
\text { Bywy } \\
\text { Benory Yri } \\
\text { Haru } \\
\text { Hawwyynimyrará / } \\
\text { Hawykynimyrará } \\
\text { Hawykyni Marahã / } \\
\text { Hawaynimyrahá } \\
\text { Waurá benorá }\end{array}$ \\
\hline $\begin{array}{l}\text { Referência } \\
\text { à flora }\end{array}$ & $\begin{array}{l}\text { Cipó } \\
\text { Coité preto } \\
\text { Espinho }\end{array}$ & $\begin{array}{l}\text { Wery } \\
\text { Ixalabu } \\
\text { Anontí }\end{array}$ \\
\hline
\end{tabular}

Quadro 2. Correlação entre padrão gráfico, elementos da natureza e cosmologia karajá. 
Há desenhos considerados como criações livres das ceramistas como nos explicou Dyrity (Jandira) em Aruanã ao ver as fotos da coleção de Mário Ferreira Simões. Outros desenhos foram descritos por ela como "início da pintura" ou, classificados como "pintura dos joelhos" ou " faixas/listras nas pernas e braços".
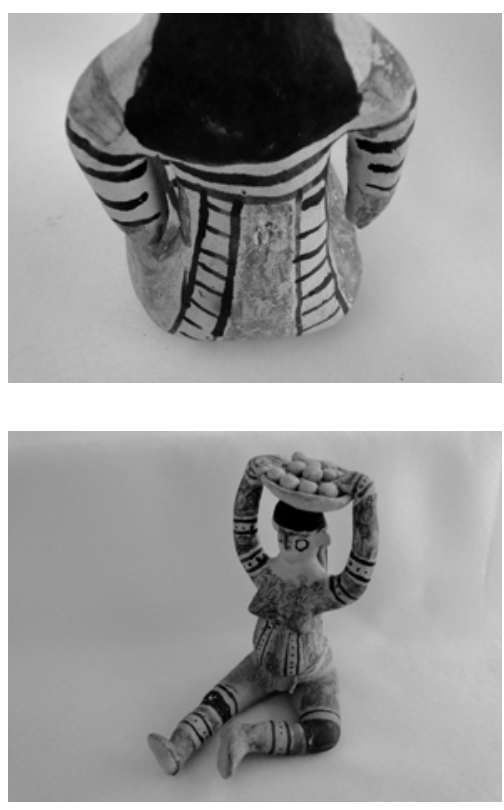

Figura 5. Kyrinaty. Início da Pintura nas costas (Coleção Mário Ferreira Simões, constituída entre os anos de 1954 e 1956). Centro Cultural Jesco von Puttkamer (PUC-60), Goiânia. Foto: Manuel Ferreira Lima Filho, 2009.

Figura 6. Dikohulyby. Pintura de uma faixa larga de cor preta nos joelhos (Coleção Mário Ferreira Simões, constituída entre os anos de 1954 e1956). Centro Cultural Jesco von Puttkamer (PUC-G0), Goiânia. Foto: Manuel Ferreira Lima Filho, 2009.
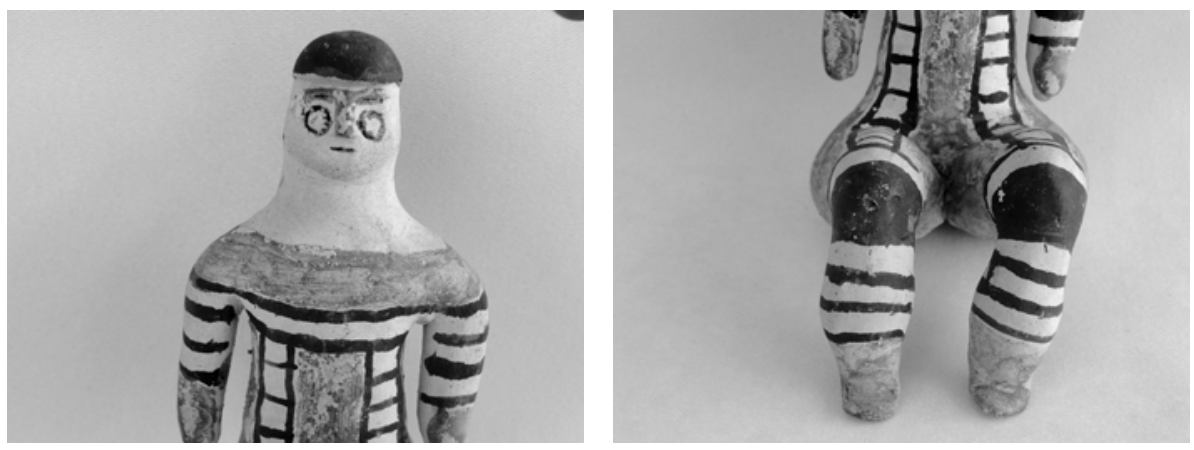

Figura 7. Iyekró. Padrão típico de braços e joelhos (Colecão Mário Ferreira Simões, constituída entre os anos de 1954 e 1956). Centro Cultural Jesco von Puttkamer (PUC-60), Goiânia. Foto: Manuel Ferreira Lima Filho, 2009. 
Existem padrões que são classificados por gênero, como Oé Oé Hawyy riti - pintura de mulher -, baseados em outros parâmetros classificatórios como a pintura feita numa cuia Tariruku itxó usada para guardar óleo de babaçu quando é usado para passar com algodão nos cabelos ou ainda os Haru, metade do desenho de um mosquito da praia.
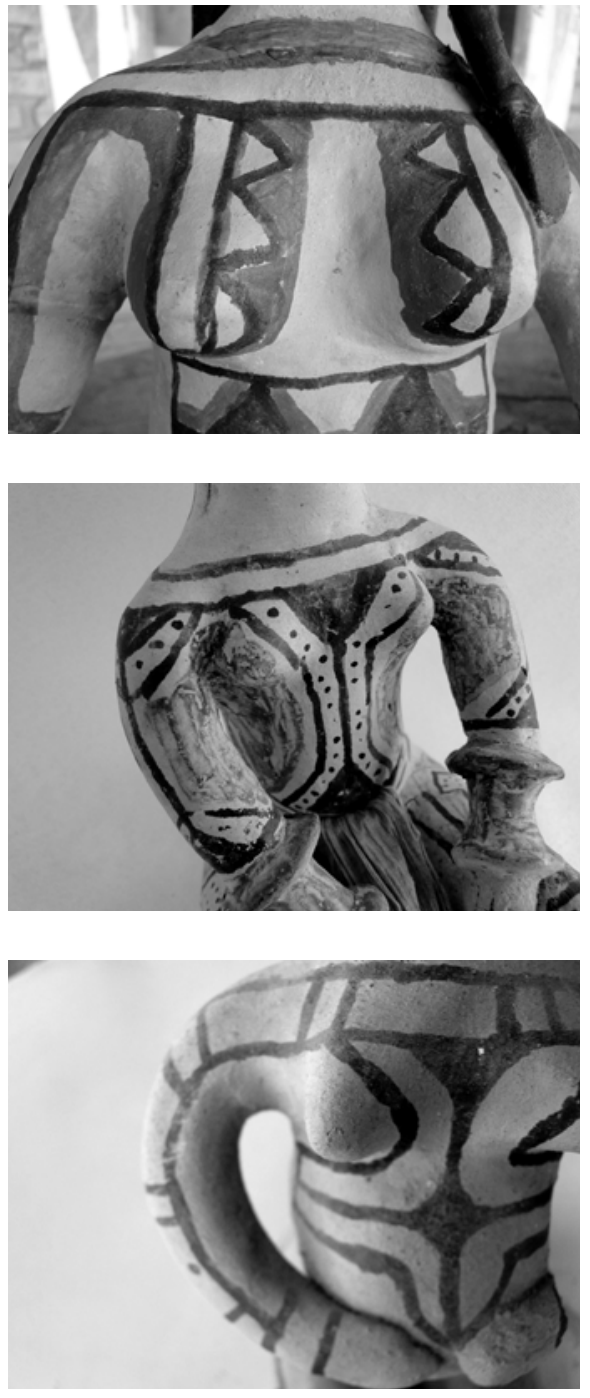

Figura 8. Oé Oé Hawyy riti. Pintura de mulher identificada por Karitxama Karajá, aldeia Buridina, Aruanã (60). Manuel Ferreira Lima Filho, 2010.

Figura 9. Pintura Tariruku itxó (Coleção Mário Ferreira Simões, constituída entre os anos de 1954 e 1956). Centro Cultural Jesco von Puttkamer (PUC-G0), Goiânia. Foto: Manuel Ferreira Lima Filho, 2009.

Figura 10. Haru identificado por Welaki Karajá, aldeia Buridina, Aruanã (GO). Manuel Ferreira Lima Filho, 2010. 


\section{0 grafismo e as interpretacõos}

As bonecas de cerâmica constituem um dos vários suportes nos quais os Karajá exercitam a arte do grafismo. Maria Heloísa Fénelon Costa (1978, p. 111-112) e Chang Whan (2010, p. 172-173) assinalam que o uso de padrões gráficos comuns nas bonecas são os mesmos usados na pintura corporal.

André de Amaral Toral (1992, p. 193) considera que, além da aplicação na decoração das cerâmicas, os desenhos da pintura corporal aparecem também na feitura das máscaras, na cestaria e nas esteiras. Silva (2010, p. 7) acrescenta que os padrões gráficos são utilizados também na produção de artefatos masculinos como remos, arcos, flechas, bancos ritualísticos e na confecção de miniaturas de arcos e flechas e de barcos, estes destinados ao comércio implementado pelo turismo. Os grafismos aparecem também em maracás e em objetos produzidos com o uso de miçangas. Neste último caso, a pesquisadora observa que os motivos surgem do trançado de fios e contas na urdidura do Maranin (colar usado em cerimônias como na dança de Aruanã) ou, em adornos usados no cotidiano por adultos e crianças independente do gênero.

No que se refere especificamente aos estudos que focalizam o grafismo aplicado às bonecas de cerâmica, algumas características podem ser apontadas:

Quanto aos motivos: são geométricos e estão presentes em outros artefatos. Há padrões básicos e padrões derivados que operam por meio de combinações, de entrecruzamento de linhas e pela distribuição no espaço. Alguns dos desenhos corporais mais comuns são as listras e faixas pretas, usadas nos braços e pernas, reproduzidas nas Ritxoko, predominantemente usadas pelos mais velhos por ser considerada uma pintura discreta e de fácil execução (Costa, 1978, p. 109).

Para a pesquisadora, outro padrão favorito é a grega e suas variantes, usada indistintamente por homens e mulheres, e por diferentes grupos de idade. A antropóloga Edna Luisa Taveira (2002, p. 25) observou:

São vários os padrões usados caracterizando-se pela combinação de linhas horizontais e verticais, numa composição geométrica de gregas quátricas. Os desenhos, pelos nomes que lhes são dados, representam partes do corpo, da fauna terrestre e aquática: formiga, cobra, urubu, morcego, peixe, tartaruga, mas nunca o animal no todo. Podem ocorrer também motivos ornamentais interpretados como elementos da natureza: "caminho sem fim", "forquilha", etc. O único 
motivo ornamental que foge a essa regra encontra-se na decoração de alguns potes, pratos cerimoniais, figuras fantásticas e maracás nos quais aparece representada a máscara de Aruanã.

Quanto à aprendizagem dos padrões: Taveira (2002) assinala que os motivos que se constituem como padrões tradicionais são ensinados pelos mais velhos e mais habilidosos às crianças, que os reproduzem nas areias das praias do Araguaia. Para ela, "a prática do desenho, portanto, se insere no processo educativo Karajá, que impõe normas de uso conforme idade, sexo e papel social" (Taveira, 2002, p. 25).

No que se refere à reprodução da memória coletiva é importante reportar a Toral (1992, p. 206), que chama a atenção para o fato de que a pintura corporal, por exemplo, estaria a principio inspirada em um tempo mítico ideal dos "antigos". O pesquisador pondera também que o que se observa na prática é uma originalidade nas versões apresentadas, pois os desenhos teriam sido obtidos pelo herói mitológico Kynyxiwe que na própria narrativa aponta para a incorporação de elementos novos entre os quais a reelaboração de desenhos muitas vezes decorrentes do contato interétnico.

Kynyxiwe tem um papel central na mitologia karajá, pois é por meio de suas ações que as coisas foram obtidas e nominadas. O conjunto de mitos envolvendo esse personagem é fundamental para o entendimento das figuras modeladas e pintadas pelas ceramistas.

Lima Filho (1994, p. 140) analisa o mito de como Kynyxiwe, ao criar tudo que existe, descreve como plantas rasteiras produziram emaranhados de flores e folhas e como os Karajá teceram as esteiras com desenhos e tornaram o chão mais macio. Maria Heloisa Fénelon Costa (1978, p. 129), da mesma maneira, descreve as vantagens que Kynyxiwe obteve para os Karajá como a luz do sol, da lua e das estrelas, o machado, a canoa, além dos enfeites tomados de Xiburè ou o urubu-rei. Lima Filho (1989) também apresenta uma das versões do mito publicado por Aytai (1979), em que o personagem central seria Tainahakỹ, que corta o cabelo do passarinho Hireni e coloca urucum no olho para enfeitar. Já Donahue Jr. (1982) descreve o mito de Tainahakỹ que desce velho do céu e se torna novo, todo enfeitado com braceletes e colares, com o corpo pintado de jenipapo para se casar e ensina aos Karajá a fazer roças. Já no mito sobre a origem do arco-íris ou do dilúvio, Aytai (1978) informa como a chuva em forma de um personagem mítico é encontrado pelos Karajá num buraco e depois de pedir fumo para um velho, que fumava num 
cachimbo, pega o carvão e começa a se pintar com o carvão e cinzas do cachimbo. Karitxama (Darcilia Uassuri), ceramista da aldeia Buridina, contou uma versão de como os Karajá adquiriram o conhecimento da pintura tendo como ator principal, o herói mitológico Kynyxiwe.

A obtenção das coisas pelo herói mitológico se dá a partir de relações com seres e animais. Inspirado nessa observação André de Amaral Toral (1992, p. 207) afirma que:

As incorporações e mudanças ocorridas no desenho e pintura corporal nesse quase um século de registros parecem se explicar pelas ideias contidas no mito. Com o contato definitivo e o convívio cotidiano com a população brasileira, o desenho passou por consideráveis mudanças, especialmente se pensarmos nas adaptações realizadas para a aplicação em artefatos que passaram a produzir para venda. Ele se alterou à maneira da sociedade Karajá, altamente interessada na incorporação de novos elementos e informações e obtendo nesse intercâmbio o maior número de vantagens possível $[\ldots]$

Nesse sentido, é interessante observar que podemos visualizar dois sistemas de representações disponíveis ao artista karajá para inspirar suas criações: o mundo tradicional e o mundo advindo do contato interétnico. Mundos entrelaçados no processo de reprodução cultural. As bonecas karajá são fabricadas a partir desse contexto intercultural.

O mundo do tempo antigo pode ser maximizado pela representação mítica do Koboí, o chefe de todos, e por um conjunto de personagens e seres mágicos, como os Worysy, Kynyxiwe, Teribrè, Xiburè, Tayná, Aõni Aõni, os Ijasò, entre outros. Algumas destas figuras são representadas nas criações das ceramistas que Costa (1978, p. 56-61) chamou de "figuras estranhas", tais como: Wajoramani, Txyreheni, Hiré, Benorá, Krerá, Koboí, além de figuras bicéfalas e multicéfalas.

No ritual de iniciação masculina, conhecido como Hetohoky ou casa grande, os homens também se dividem em homens de cima, homens de baixo e homens do meio e, na disposição espacial das casas rituais, igualmente tem-se a casa pequena (rio abaixo), a casa grande (rio acima) e casa de Aruanã, que fica sempre no meio destas. Portanto, a localização das aldeias karajá possui uma razão de ser nesse ou naquele local com relação ao Araguaia, assim como a disposição das casas de moradia, dos cemitérios, das casas rituais, segundo um simbolismo próprio da cultura karajá (Lima Filho, 1994). 
Os mitos abordam temas muito variados, como a origem, o extermínio e o recomeço dos Karajá, a origem da agricultura, o veado e o fumo, a origem da chuva, a origem do sol e da lua, a origem dos aruanãs, as mulheres guerreiras, a origem do homem branco, as mulheres e o jacaré, a origem do arco-íris, o dilúvio, os pirarucus, a façanha de dois irmãos, entre muitos outros (Lima Filho, 1989). Normalmente esses mitos estão associados aos rituais e aos temas sociais, como as relações de gênero, o casamento, o xamanismo e o poder político, as doenças e a morte, o parentesco, as plantações, as pescarias, os enfeites e o contato com os brancos.

A estrutura ritual dos Karajá tem dois grandes cerimoniais como referências: o rito de iniciação masculina, o Hetohoky, e a Festa de Aruanã, que apresentam ciclos anuais, fundados na subida e descida das águas do rio Araguaia. Entre outros pequenos ritos, podem ser citados a pescaria coletiva de timbó, a festa do mel, a festa do peixe, as cerimônias relacionadas à menarca (rito denominado Hiraritxanamy), além de outros inclusos nos grandes rituais dos aruanãs e do Hetohoky.

Esses três níveis cosmológicos (o céu, a terra e a água) devem estar em equilíbrio para manter a vida em sociedade segura. Todas as ações dos rituais, dos xamãs e das chefias tradicionais e ritualísticas buscam manter a estabilidade do edifício cósmico (Pétesch, 1993).

Assim, na perspectiva da manutenção do tempo dos antigos, cíclico, de autorreprodução do Koboí fechando a passagem para a contagem do tempo linear e a espacialidade, encontram-se os padrões de desenhos tradicionais e formas das bonecas.

Nesse contexto, podem ter sentido as observações da antropóloga Patrícia Mendonça de Rodrigues (1993, 2008), enquanto exercício analítico baseado em longos trabalhos de campo entre os Javaé, e dados da etnografia sobre a cesta karajá de Edna Luisa de Melo Taveira (1982), ao propor a correlação entre os padrões da natureza e da cultura do grafismo karajá. Como já citado, há recorrência etnográfica da divisão que os Karajá fazem entre três níveis cosmológicos: o céu, água e a terra. Na interpretação de Patrícia de Mendonça Rodrigues (1993), as extremidades (céu e água) se encontram em algum momento (terra/meio) que seria representado por um sistema gráfico "aberto" e um outro "fechado" presentes nos padrões de desenhos relacionados ao ciclo da infância à velhice, na subida e descida do rio Araguaia, no sêmen que sai do corpo masculino e entra no corpo feminino, no poente e no nascente, na 
pele nova/pele velha, na nascente e na foz do Araguaia. Extremidades que se encontram num mesmo ponto. Daí os inúmeros padrões Koé-Koé (voltas) e Urawo (fechado) (Lima Filho, 2010). Esses padrões tradicionais são reproduzidos também nas bonecas karajá.

Entretanto, também como previsto nos mitos, em busca de novidades e de vantagens, os Karajá são sensíveis às novidades estéticas advindas do contato nacional, deixando sempre em aberto a possibilidade de criação e interpretação dos padrões de grafismo do grupo. André de Amaral Toral (1992, p. 207) assinala essa interessante capacidade de um movimento criativo que se volta ao mundo da reprodução cultural dos "antigos", dos mitos, do tempo cíclico, da tradição e, igualmente, suscetível ao tempo histórico, do contato e das inovações:

Os muitos campos de cultura material dos Karajá - plumária, tecelagem, cestaria, escultura em madeira e barro, cerâmica, pintura corporal, artesanato para venda, fabricação dos objetos cerimoniais etc. - parecem refletir essa capacidade de aprendizado no contato com outras culturas e sociedades.

Nessa perspectiva, a tradição, como afirma Campos (2007, p. 113), deve ser entendida de forma dinâmica e com possibilidades de flexibilização: "A criação de um estilo novo não significa o abandono de práticas seculares, principalmente por envolver a mesma tecnologia de produção. Deve ser entendida como continuidade que incorporam mudanças e por sua vez criam novas tradições."

\section{Arte comunal e a singularidade da expressão artística: padrões, variacõoes e prestígio}

O homem está investido nas coisas e as coisas estão investidas nele.

Merleau-Ponty

Os Karajá mesclam o prazer de desenhar e de criar com o exercício da memória coletiva. Essa relação entre a prática prazerosa do desenho e da transmissão do saber fazer o desenho é observada no cotidiano das ceramistas em Santa Isabel do Morro. ${ }^{16}$ Muitas vezes, elas riscam grafismos no chão enquanto conversam e descrevem o modo de fazer a boneca, cenas que são

${ }^{16}$ Diferentemente de Buridina, onde a aprendizagem dos grafismos acontece em contexto escolar formal.

Horizontes Antropológicos, Porto Alegre, ano 18, n. 38, p. 45-74, jul./dez. 2012 
observadas e copiadas por suas netas, principalmente as que vivem em suas casas. ${ }^{17}$ Assim como a modelagem das bonecas e as formas que elas adquirem, a aprendizagem da pintura acontece no âmbito das famílias extensas e se caracteriza pelo lúdico em processo de socialização. As brincadeiras com as bonecas e a repetição dos desenhos no chão possibilitam ao mesmo tempo a aprendizagem dos papeis sociais e da mitologia karajá.

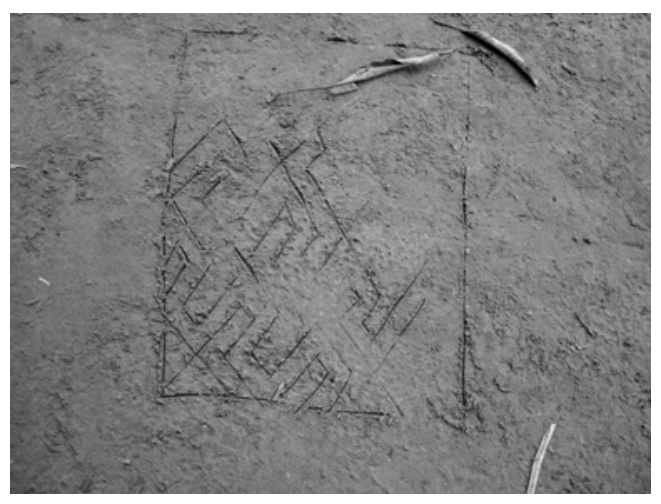

Figura 11. Grafismo feito pela ceramista Koaxiro enquanto descrevia a matéria-prima usada na pintura das bonecas. Aldeia de Santa Isabel do Morro, dezembro de 2010 (Telma Camargo da Silva - Acervo Iphan).

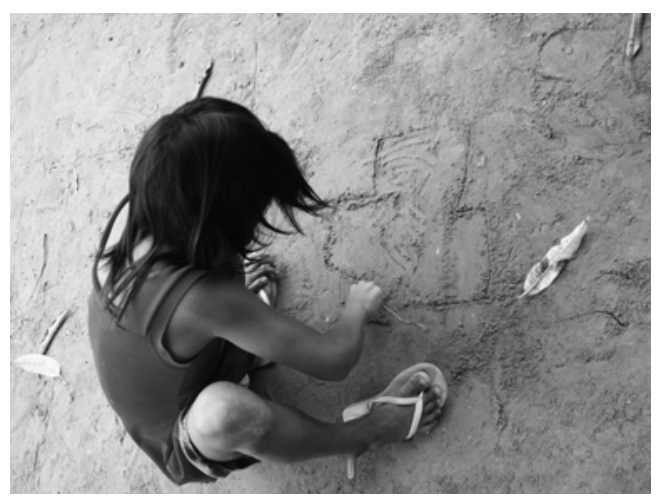

Figura 12. Neta da ceramista Koaxiro imita os desenhos feitos pela avó. Aldeia de Santa lsabel do Morro, dezembro de 2010 (Telma Camargo da Silva - Acervo Iphan).

17 De acordo com o padrão karajá de residência uxorilocal. 
O grafismo aplicado nas Ritxoko segue padrões tradicionais aos quais são acrescidos elementos da criatividade individual. Os motivos indicados como tradicionais são: Haru (losangos, ou losangos que circunscrevem linhas paralelas; ou losangos que circunscrevem triângulos pretos); Itxalabu (busto preto, pintura masculina); Koé-Koé (nome genérico dado à grega $\mathrm{e}$ suas variantes); Wedé-Wedé (pontos). A singularidade da arte da ceramista decorre da sua criatividade na combinação dos padrões tradicionais entre si e na habilidade com que os grafismos são aplicados nas bonecas e a precisão na execução dos traços.

Os exemplos abaixo ilustram esta criatividade no caso do padrão WedéWedé, em que o mesmo é usado de diferentes maneiras: a) em combinação com outras formas; b) com a aplicação de pontos formando uma linha; c) com a aplicação de um ponto dentro de um losango; d) em um conjunto de vários pontos.
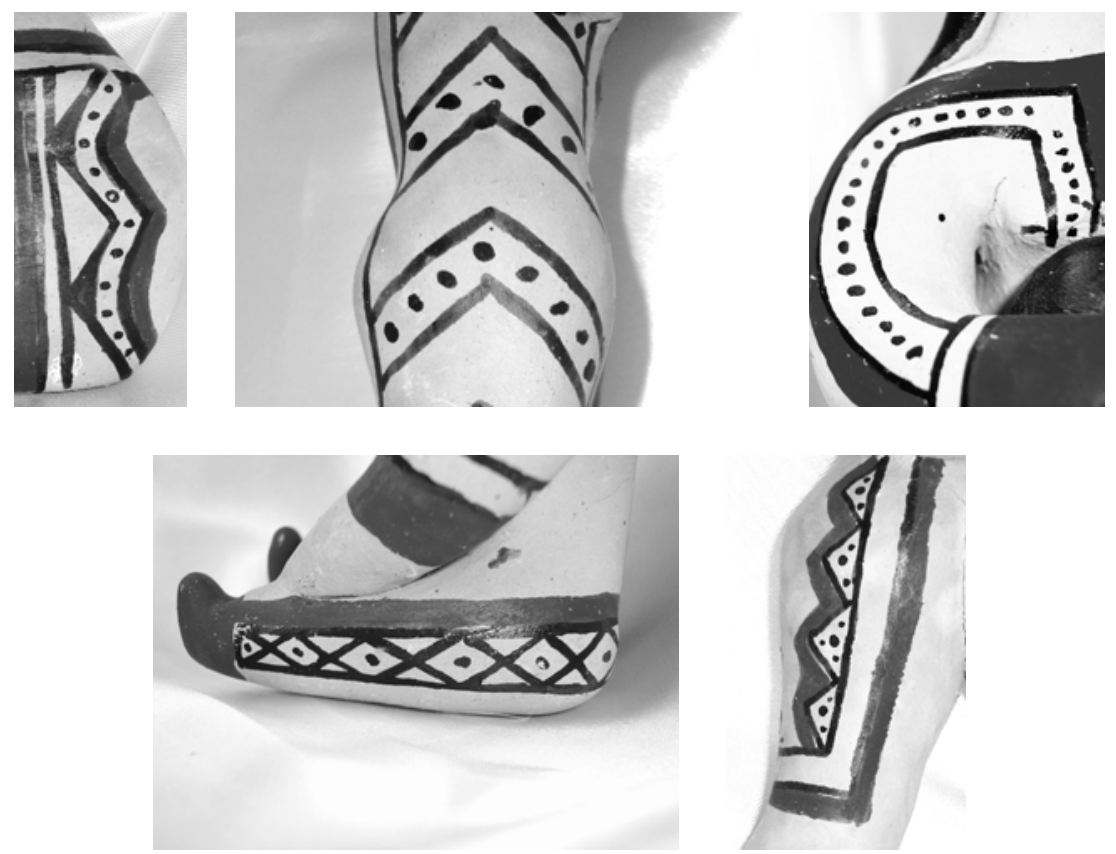

Figura 13. Variações na aplicação e combinações do motivo Wedé-Wedé (Silva, 2010, p. 106). 
Essa habilidade e a criatividade na aplicação dos grafismos são identificadas pelos membros do grupo que, ao expressarem suas avaliações, classificam as ceramistas como "boas" ceramistas. Dessa forma, reconhecem a singularidade das mesmas como artistas no conjunto daquelas que sabem executar o ofício, mas cuja obra não se individualiza.

A avaliação do grupo é expressa, por exemplo, no caso do grafismo a seguir, que, ao ser mostrado para duas mulheres mais velhas e indicadas como "boas" ceramistas (Mahuederu e Lawarideru) recebe o seguinte comentário: "Ela [a ceramista que fez a boneca] está aprendendo."

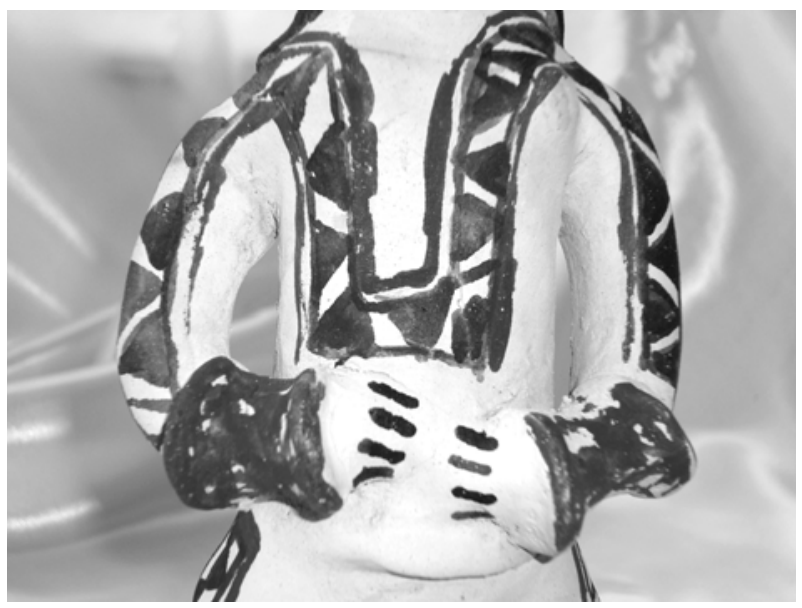

Figura 14. Grafismo classificado por algumas ceramistas como trabalho de uma "ceramista aprendiz" (Silva, 2010, p. 106-107).

O conjunto de padrões criados pelos Karajá - grafismos reconhecidos e repassados pela tradição - remete a uma arte comunal que confere ao grupo uma imagem de si mesmo. Nesse contexto de produção do saber e do ofício, pessoas identificadas como povo karajá identificam e nomeiam aquelas ceramistas que melhor atendem às características definidas pelo saber tradicional. Essas considerações são corroboradas pelas afirmações de Darcy Ribeiro (1986). Sobre a arte comunal, ele afirma: 
Esta arte comunal é a afloração maior das comunidades indígenas. Aquela que lhes confere a imagem do visível de si mesmas, de sua beleza, rigor e dignidade. Cumpre, por isso, três funções elementares: a de diferenciar o mundo dos homens, regidos pela conduta cultural que se constrói a si mesma, do mundo dos bichos, comandados por impulsos inatos, inevitáveis e incontroláveis. A de diferenciar aquela comunidade étnica de todas as outras, proporcionando um espelho em que ela se vê e se contrasta com a imagem etnocêntrica que tem de outros povos. Cumpre, ainda a função geral de dar aos homens coragem e alegria de viver. (Ribeiro, 1986, p. 31).

E sobre a expressão artística na arte comunal, ele continua:

No mundo indígena ela (a idéia ocidental de coisa artística) existe para o etnólogo que olha, reconhece e colhe os objetos "artísticos"; não tanto para os índios que os têm e os usam junto com todos os outros. Esclareça-se aqui que, apesar de usá-los conjuntamente, os índios apreciam distintivamente os espécimes que atendem melhor aos requisitos formais de perfeição de cada gênero e melhor expressam o padrão tradicionalmente prescrito, como também reverenciam muito as pessoas que conseguem fazê-los com tamanha perfeição. (Ribeiro, 1986, p. 30).

Logo, a ceramista encontra-se na confluência de dois movimentos dos quais decorrem implicações para a demarcação do seu lugar no grupo. Por um lado, ao reproduzir os padrões que lhe foram repassados pela tradição, ela contribui para a continuidade da afirmação de uma identidade karajá e ocupa o seu papel tradicional como reprodutora do mundo simbólico. Um lugar definido pelas relações de gênero em que fazer "famílias de bonecas" com o uso de padrões gráficos tradicionais e presentear as crianças com estas "famílias"18 é a reafirmação do seu papel na transmissão do conhecimento sobre a constituição do núcleo familiar karajá, do ciclo de vida e também dos elementos gráficos e formais (a modelagem) que pertencem ao saber comunal.

Por outro lado, a relação entre tradição e criatividade sugere que a ceramista tem flexibilidade no uso do grafismo aplicado na cerâmica. Para Taveira (2002, p. 26) "[...] se o uso do padrão dos desenhos geométricos deve se submeter ao código social do grupo, é na cerâmica que a interdição cessa e

18 Conjunto de pequenas figuras humanas que reproduzem uma família extensa e que são presenteadas por avós e tias às meninas quando atingem a idade de seis anos, aproximadamente (Campos, 2007; Lima et al., 2011; Whan, 2010). 
a ceramista combina padrões diversos". Ser considerada "boa" ceramista como uma artista - define um lugar singular no sistema simbólico e econômico tradicional próprio do grupo. A procura pelas suas bonecas em detrimento de outras, o dinheiro que entra na sua família e não em outras, e o seu maior poder aquisitivo para consumo de bens industriais são alguns dos elementos que apontam para uma possível configuração de poder e relações de gênero fora da representação tradicional karajá.

Mas a caracterização da boa ceramista vai além das características formais do artefato por ela produzido e da qualidade e criatividade do desenho feito. A distinção decorrente da classificação como boa ceramista interliga as dimensões da produção do artefato (modelagem, queima e pintura) à de circulação desses bens no mercado consumidor externo (museus, antropólogos, casas de artesanato, entre outros). De certa forma, são as relações de afiliação política interna à aldeia e de parentesco da ceramista com as lideranças locais que conferem visibilidade ao seu trabalho além daquele atribuído pela Ritxoko como brincadeira infantil. É essa visibilidade que confere legitimidade e reforça as características formais do desenho produzido como "bem feito", "bonito". Como de uma forma geral as ceramistas não falam a língua portuguesa e raramente circulam fora de suas aldeias sem a presença masculina, a circulação dos artefatos dependem de uma mediação masculina. Nesse sentido, o artefato sinaliza para os papéis tradicionais de gênero.

Contudo, quando o resultado do produto comercializado retorna para as famílias em forma de bens da sociedade de consumo - DVD, TV, fogão a gás, roupas, celulares - as mulheres ceramistas adquirem uma outra forma de prestígio diferente dos assegurados pela socialização karajá. A "boa ceramista" condensa então na modelagem e pintura das bonecas, a reprodução dos mitos e o relato modelado em barro das cenas do cotidiano, sinaliza a rede social de pertencimento e materializa - como resultado dos bens produzidos e consumidos - uma nova posição no contexto das relações internas à aldeia.

Essa constatação nos leva a refletir sobre a tensão entre os gêneros. Os homens são socializados para serem portadores de uma boa performance oral praticada nos espaços rituais, construindo lideranças e fortalecendo a rede de solidariedade entre parentes consaguíneos masculinos em contraposição aos parentes masculinos por afinidade: sogros e cunhados. As mulheres antecedem as decisões masculinas tomadas na casa dos homens em suas unidades uxorilocais e têm seu prestigio crescente à medida que envelhecem, se tornam

Horizontes Antropológicos, Porto Alegre, ano 18, n. 38, p. 45-74, jul./dez. 2012 
Manuel Ferreira Lima Filho e Telma Camargo da Silva

avós e particularmente xamãs. E também, no caso específico da confecção de bonecas - e grafismo - na medida em que passam de aprendizes a mestras do ofício de saber fazer Ritxoko (Lima et al., 2011), e principalmente quando entram na classificação nativa de "boas ceramistas". A circulação do dinheiro e de bens nas mãos das ceramistas pode significar a ultrapassagem de um limite de prestígio culturalmente aceito e que potencializaria uma agressividade entre os gêneros prevista nos mitos/ritos (Rodrigues, P., 1993). No contexto histórico karajá, marcado pelas consequências impactantes do contato interétnico, o fato de algumas mulheres ceramistas romperem limites e padrões culturais pode engendrar complexas relações onde prestígio, poder e agressividade estariam sendo tecidas.

\section{Referências}

APPADURAI, A. Toward an anthropology of things. In: APPADURAI, A. (Ed.). The social life of things: commodities in cultural perspective. London: Cambridge University Press, 2006. p. 3-63.

AYTAI, D. Um mito karajá: a história do arco-íris. Publicações do Museu Municipal de Paulinia, n. 5, p. 20-21, ago. 1978.

AYTAI, D. Weheriá Karajá conta a lenda do sol. Publicações do Museu Histórico de Paulínia, n. 8, p. 7-12, maio 1979.

CAMPOS, S. L. Bonecas karajá: apenas um brinquedo? Revista do Museu de Arqueologia e Etnologia, São Paulo, n. 12, p. 233-248, 2002.

CAMPOS, S. M. C. de la T. L. Bonecas karajá: modelando inovações, transmitindo tradições. Tese (Doutorado em Antropologia)-Departamento de Ciências Sociais - Antropologia,Pontifícia Universidade Católica de São Paulo, São Paulo, 2007.

COSTA, M. H. F. A arte e o artista na sociedade karajá. Brasília: Fundação Nacional do Índio, 1978.

COSTA, M. H. F.; MALHANO, H. B. Habitação indígena brasileira. In: RIBEIRO, B. (Org.). Suma etnológica brasileira: 2 - tecnologia indígena. São Paulo: Vozes, 1986. p. 27-94. 
DONAHUE JR., G. R. A contribution to the ethnography of the karajá indians of central Brazil. Tese (Doutorado em Antropologia)-University of Virginia, Charlottesville, 1982.

EHRENREICH, P. Contribuições para a etnologia do Brasil. Revista do Museu Paulista, São Paulo: Museu Paulista, v. 2, p. 7-135, 1948.

FABIAN, J. Colecionando pensamentos: sobre os atos de colecionar. Mana, v. 16, n. 1, p. 59-73, abr. 2010. Disponível em: <http://www.scielo.br/scielo. php?script=sci_arttext\&pid=S0104-93132010000100003\&lng=pt\&nrm=iso \&tlng=pt>. Acesso em: 28 fev. 2012.

FARIA, L. de C. A figura humana na arte dos índios Karajá. Rio de Janeiro: Universidade do Brasil/Museu Nacional, 1959.

FUNDAÇÃO NACIONAL DE SAÚDE. Censo: Distrito Sanitário Especial Indígena: DSEI-Araguaia. São Felix do Araguaia, 2011.

GONÇALVES, J. R. Antropologia dos objetos: coleções, museus e patrimônios. Rio de Janeiro: Iphan, 2007.

JEUDY, H.-P. Espelhos das cidades. Rio de Janeiro: Casa da Palavra, 2005

KOPYTOFF, I. The cultural biography of thing: commoditization as process. In: APPADURAI, A. (Ed.). The social life of things: commodities in cultural perspective. London: Cambridge University Press, 2006. p. 64-91.

KRAUSE, F. Nos sertões do Brasil. Revista do Arquivo Municipal, São Paulo: Arquivo Municipal, v. 66-91, 1940-1943.

LIMA FILHO, M. F. Os filhos da água: uma reflexão sobre a cosmologia karajá. Brasília: UnB, 1989. Manuscrito.

LIMA FILHO, M. F. Hetohoky: um rito karajá. Goiânia: Editora UCG, 1994.

LIMAFILHO, M. F. Karajá. In: ENCICLOPÉDIA DOS POVOS INDÍGENAS. 1999. Disponível em: <http://pib.socioambiental.org/pt/povo/karaja $>$. Acesso em: 28 fev. 2012. 
LIMA FILHO, M. F. Entre a paixão e a técnica: reflexões sobre o processo de identificação e demarcação das terras dos Karajá de Aruanã (GO). In: LIMA, A. C. de S.; BARRETTO FILHO, H. T. Antropologia e identificação. Rio de Janeiro: Contra-Capa, 2005. p. 323-353.

LIMA FILHO, M. F. Cidades patrimoniais e identidades nacionais: questões antropológicas na perspectiva comparativa entre o Brasil e os Estados Unidos. In: BEZERRA, M.; LIMA FILHO, M. F. Os caminhos do patrimônio no Brasil. Goiânia: Alternativa, 2006.

LIMA FILHO, M. F. Considerações sobre o grafismo karajá na perspectiva dos Karajá de Aruanã (GO). Relatório técnico. Goiânia: UFG: Iphan, 2010.

LIMA FILHO, M. F. Entre campos: cultura material, relações sociais e patrimônio. In TAMASO, I.; LIMA FILHO, M. F. Antropologia e patrimônio cultural: trajetórias e conceitos. Goiânia: UFG: ABA: Capes, 2012. No prelo.

LIMA, N. C. et al. Bonecas karajá: arte, memória e identidade indígena no Araguaia: dossiê descritivo do modo de fazer ritxoko. Goiânia: Universidade Federal de Goiás/Museu Antropológico, 2011.

LIPKIND, W. The Carajá. In: STEWARD, J. (Ed.). Handbook of South American Indians: v. 3. Washington: Smithsonian Institution Bureau of American Ethnology, 1948. p. 179-191.

MALINOWSKI, B. Argonautas do Pacifico Ocidental. São Paulo: Abril Cultural, 1978.

MAUSS, M. Sociologia e antropologia. São Paulo: Cosac \&Naify, 2003.

MERLEAU-PONTY, M. Conversas - 1940. São Paulo: Martins Fontes, 2004.

MINISTÉRIO DA EDUCAÇÃO. Adornos e pintura corporal Karajá. Goiânia: Editora da Universidade Federal de Goiás, 1995.

MURA, F. A trajetória dos chiru na construção da tradição de conhecimento kaiowa. Mana, v. 16, n. 1, p. 123-150, 2010. Disponível em: <http://www. scielo.br/pdf/mana/v16n1/a06v16n1.pdf>. Acesso em: 28 fev. 2012. 
MURA, F. De sujeitos e objetos: um ensaio crítico de antropologia da técnica e da tecnologia. Horizontes Antropológicos, ano 17, n. 36, p. 95-125, jul./dez. 2011.

PÉTESCH, N. A triologia karajá: sua posição intermediária no continuum jê-tupi. In: VIVEIROS DE CASTRO, E.; CUNHA, M. C. da. Amazônia: etnologia e história indígena. São Paulo: Núcleo de História Indígena e do Indigenismo da USP; Fapes, 1993. p. 365-382.

RIBEIRO, Berta G. "A linguagem simbólica da cultura material”. SUMA Etnológica Brasileira. Petrópolis: Vozes. № 3. 1986, pp. 15-27.

RIBEIRO, D. Arte índia. SUMA Etnológica Brasileira, Petrópolis: Vozes, n. 3, p. 29-64, 1986.

RODRIGUES, A. D. Línguas brasileiras para o conhecimento das línguas indígenas. São Paulo: Loyola, 1986.

RODRIGUES, P. de M. O povo do Meio: tempo, cosmo e gênero entre os Javaé da ilha do Bananal. Dissertação (Mestrado em Antropologia)-Universidade de Brasília, Brasília, 1993.

RODRIGUES, P. de M. A caminhada de Tanyxiwè: uma teoria javaé da história. Tese (Doutorado em Antropologia)-University of Chicago, Chicago, 2008 .

RONDON, A. L. D. da F. A boneca ritxokó: corpos fluidos da cultura karajá. Dissertação (Mestrado em Artes)-Instituto de Artes, Universidade do Estado do Rio de Janeiro, Rio de Janeiro, 2011.

SAVIOLA, D. I Karajá dell Araguaia. In: NOBILI, C.; SAVIOLA, D. I segni del tempo: arte, cultura e storia di ter etnie del Brasile. Roma: Edizioni Sean Roma, 1995. p. 45-47. Catálogo de exposição, Museo Nazionale Preistorico Etnografico Luigi Pegorini.

SILVA, T. C. da. Primeiras aproximações ao grafismo aplicado às ritxoko - Aldeia Santa Isabel do Morro (Hawaló), Ilha do Bananal (TO). Relatório técnico. Goiânia: UFG: Iphan, 2010. 
SILVEIRA, F. L. A. da; LIMA FILHO, M. F. Por uma antropologia do objeto documental: entre a "a alma nas coisas" e a coisificação do objeto. Horizontes Antropológicos, ano 11, n. 23, p. 37-50, jan./jun. 2005.

SIMÕES, M. F. Cerâmica karajá e outras notas etnográficas. Organizadores: Manuel Ferreira Lima Filho e Maria Eugênia Brandão Alvarenga Nunes. Goiânia: UCG Editora, 1992.

TAVEIRA, E. L. de M. Etnografia da cesta karajá. Goiânia: Editora da Universidade Federal de Goiás, 1982.

TAVEIRA, E. L. de M. Arte indígena Karajá. In: MENEZES, A. Da caverna ao museu: dicionário de artes plásticas em Goiás. Goiânia: Agência Goiana de Cultura Pedro Ludovico Teixeira, 2002. p. 27.

TORAL, A. de A. Pintura corporal karajá contemporânea. In: VIDAL, L. (Org.). Grafismo indígena. São Paulo: Edusp: Nobel, 1992. p. 191-208.

WHAN, C. Ritxoko: a voz visual das ceramistas Karajá. Tese (Doutorado em Artes Visuais)-Escola de Belas Artes, Universidade Federal do Rio de Janeiro, Rio de Janeiro, 2010.

WUST, I. A cerâmica karajá de Aruanã. Anuário de Divulgação Científica, v. 2, n. 2, p. 96-165, jun. 1975. 